\title{
OVERVIEW SELF EFFICACY OF SPIRITUAL AND PATIENTS HIV/AIDS IN THE PROVINCE BENGKULU
}

\author{
Ismatul Zahara ${ }^{1}$, Sardaniah $^{2}$, Tuti Anggriani Utama ${ }^{3}$ \\ ${ }^{1,2,3}$ Universitas Bengkulu
}

Email : ismatulzahara34@gmail.com

\begin{abstract}
Our objective is to see the picture of self-efficacy, and the level of spirituality of HIV / AIDS patients in Bengkulu Province. The results of this study can be used to increase the client's knowledge about the importance of self-efficacy, and spiritual level of the HIV / AIDS patient itself. Its Benefits As an ingredient consideration for further research as well as motivating researchers to read the latest issues and trends regarding HIV / AIDS, especially in the Province Bengkulu. using this type of descriptive research in order to explain how to describe self-efficacy and spiritual level in HIV / AIDS patients at Bengkulu Province. (Nursalam 2008, in Henni, 2011) The population in this study are all HIV / AIDS positive clients, amounting to 177 people in the Province Bengkulu.used was Thepurposive sampling sample123 people were sampled with certain criteria (Hardani, 2020). The results show most PLHIV in Bengkulu Province in this study have self efficacy sufficientthat about 24 out of 50 respondents enter into it category of ODHA with Self Efficacy sufficient. and on spiritual variables some ODHA respondents in Bengkulu Province have a high spiritual level where this is supported by the results of the study that of the 50 respondents 41 people fall into the category of a high spiritual level. The benefits of research can be additional literature for nursing institutions regarding aspects of self-efficacy and spiritual in order to create a characteristic nurse. ODHA is expected to increase knowledge about Self Efficacy and Spiritual level in order to be able optimize existing support and guidance resources. Researchers hope there is further research related to other factors that affect health especially for people living with HIV / AIDS. .
\end{abstract}

Keywords: ODHA, Self-Efficacy, Spiritual Level

\section{PENDAHULUAN}

Penyakit HIV/AIDS merupakan suatu penyakit yang terus berkembang dan menjadi masalah global yang melanda dunia. Menurut data WHO (World health Organization) pada tahun 2015, penemuan kasus HIV/AIDS 36,7 juta penderita, dimana sebanyak 1,1 
juta penderita meninggal karena AIDS (WHO, 2017). Human Immunodeficiency Virus (HIV) merupakan penyakit yang diakibatkan oleh infeksi virus HIV dan merupakan salah satu penyakit infeksi menular seksual yang bersifat kronis (Superkertia, Astuti \&Lestari, 2016). Acquired immunodefiency syndrome (AIDS) merupakan penyakit kronik progresif yang disebabkan human immunodeficiency virus (HIV), menyebabkan morbiditas secara signifikan sampai saat ini dan untuk sebagian orang dapat berakibat fatal. Angka estimasi penderita HIV dan AIDS di seluruh dunia adalah 36.9 juta sampai saat ini, dengan perkiraan 2 juta kasus baru dan 1.2 kematian per tahun (Collein, I., 2010; Souza, P.N., et al., 2016).

Berdasarkan data dari Dinas Kesehatan Provinsi Bengkulu terdapat 177 data pasien HIV/AIDS. Pada tahun 2019 terdapat 112 kasus yang tercatat dalam hal tersebut tercatat faktor resiko pada kasus HIV/AIDS diantaranya yaitu Wanita Pekerja Seks (WPS) (14\%), Pelanggan Pekerja Seks (PPS) (0\%), Waria (4\%), Laki Seks Laki (22\%), Injecting Drug User (IDU) (0\%), Pasangan Resiko Tinggi (29\%), Pekerja Seks (27\%), lain-lain (16\%) (Dinkes, 2019). Jika digolongkan berdasarkan jenis kelaminnya kasus HIV/AIDS Provinsi Bengkulu tahun 2019 diantaranya yaitu Laki-laki (77\%) dan Perempuan (35\%). Jumlah kasus HIV pada Laki-laki ditahun 2019 mencapai angka 63 kasus sedangkan pada Perempuan mencapai 27 kasus, pada AIDS sendiri kasus yang terkonfirmasi pada Laki-laki mencapai 14 kasus, sedangkan pada Perempuan sebanyak 8 kasus. Pada periode Januari sampai dengan juni tahun 2020 kasus terkonfirmasi HIV berjumlah 16 kasus, sedangkan pada kasus AIDS sendiri mencapai angka 13 kasus, jadi terkonfirmasi kasus HIV/AIDS pada tahun 2020 untuk periode januari sampai juni adalah 29 kasus.

Berdasarkan fenomena yang muncul maka, peneliti tertarik untuk mengetahui bagaimana gambaran self efficacy dan kebutuhan spiritual pasien HIV/AIDS di Provinsi Bengkulu. 


\section{METODE}

Pada penelitian ini menggunakan jenis penelitian deskriftif dengan tujuan untuk menjelaskan bagaimana gambaran self efficacy dan tingkat spiritual pada pasien HIV/AIDS di Provinsi Bengkulu. Populasi pada penelitian ini adalah semua klien positif HIV/AIDS yang berjumlah 177 orang di Provinsi Bengkulu dan Sampel yang digunakan adalah Purpusive Sampling sebanyak 123 orang yang dijadikan sampel dengan kriteria tertentu. Jenis data dalam penelitian yang penulis gunakan adalah data primer dan data sekunder serta Teknik Penelitian ini dilakukan dengan observasi, wawancara, dan pemberian angket atau kusioner. Teknik pengolahan data dilakukan melalui suatu proses dengan tahapan Editing, Coding, Entry, Cleaning, Skoring.

\section{HASIL}

Karakteristik Responden

a. Jenis Kelamin

Tabel 1. Distribusi Frekuensi Karateristik Responden Berdasarkan Jenis Kelamin Pasien HIV/AIDS di Provinsi Bengkulu.

\begin{tabular}{clccc}
\hline No & & Variabel & F & \% \\
\hline 1. & Laki-laki & 36 & $72 \%$ \\
2. & Perempuan & 14 & $28 \%$ \\
\hline \multicolumn{2}{r}{ Total } & & 50 & $100 \%$ \\
\hline
\end{tabular}

Berdasarkan tabel 1.2 diatas menjelaskan bahwa responden lebih dominan pada jenis kelamin laki-laki sebanyak 36 responden (72\%).

b. Usia

Tabel 2. Distribusi Frekuensi Karateristik Respnden Berdasarkan Usia Pasien HIV/AIDS di Provinsi Bengkulu

\begin{tabular}{crccc}
\hline No & & Variabel & F & \% \\
\hline 1. & $<30$ & 27 & $54 \%$ \\
2. & $>30$ & 23 & $46 \%$ \\
\hline \multicolumn{2}{c}{ Total } & 50 & $100 \%$ \\
\hline
\end{tabular}

Berdasarkan tabel 1.3 sebagian besar responden berusia diibawah 30 tahun (54\%). 
c. Self Efficacy

Tabel 3. Distribusi Frekuensi Karakteristik Responden Berdasarkan Variabel Self Efficacy Pasien HIV/AIDS di Provinsi Bengkulu

\begin{tabular}{|c|c|c|c|}
\hline No & Self Efficacy & $\mathbf{F}$ & $\%$ \\
\hline 1. & Baik & 20 & $40 \%$ \\
\hline 2. & Cukup & 24 & $48 \%$ \\
\hline 3. & Kurang & 6 & $12 \%$ \\
\hline
\end{tabular}

Berdasarkan tabel 1.4 menjelaskan Self Efficacy Pasien HIV/AIDS di Provinsi Bengkulu itu berada pada kategori self efficacy cukup itu 24 orang (48\%).

d. Tingkat Spiritual

Tabel 4. Distribusi Frekuensi Karakteristik Responden Berdasarkan Variabel Tingkat Spiritual Pasien HIV/AIDS di Provinsi Bengkulu.

\begin{tabular}{cccc}
\hline No & Tingkat Spiritual & F & Persentase (\%) \\
\hline 1. & Spiritual Rendah & 1 & $2 \%$ \\
2. & Spiritual Sedang & 8 & $16 \%$ \\
3. & Spiritual Tinggi & 41 & $82 \%$ \\
\hline \multicolumn{2}{c}{ Total } & 50 & $100 \%$
\end{tabular}

Berdasarkan tabel 1.5 menjelaskan bahwa tingkat spiritual Pasien HIV/AIDS di Provinsi Bengkulu itu spiritual tinggi 41 orang (82\%).

\section{PEMBAHASAN}

1. Self Efficacy

Berdasarkan hasil tabulasi data didapatkan bahwa sebagian besar ODHA di Provinsi Bengkulu memiliki keyakinan atau self efficacy yang cukup. Hal ini terbukti dengan hasil penelitian bahwa keseluruhan responden yang diteliti dapat diketahui sekitar 20 orang self efficacy nya baik, 24 orang self efficacy nya cukup, dan sisanya 6 orang self efficacy kurang. Hasil penelitian ini sesuai dengan hasil penelitian yang dilakukan Mey Selvi tahun 2017 bahwa hasil 
tabulasi data menunjukan hasil self efficacy yang Cukup dengan tabulasi self efficacy cukup 20 orang Dalam persentasi $67 \%$ (Mey et.al., 2017). Dari beberapa penelitian tersebut didapatkan penelitian yang tidak mendukung dengan hasil peneliti, penelitian tersebut dari Ch Yeni Kustanti dan Reni Pradita yang menyatakan bahwa sebagian besar penderita HIV/AIDS dalam mengkonsumsi ARV di LSM Kebaya Yogyakarta Tahun 2017 memiliki self efficacy yang tinggi yaitu $(87,5 \%)$ karena orang dengan HIV/ AIDS memiliki keyakinan akan manfaat ARV sehingga mampu mengatur pengobatan. Perbedaan pendapat ini karena pada penelitian ini tidak meneliti hubungan self efficacy dengan konsumsi ARV atau Antiretroviral pada pasien dengan HIV/AIDS (Ch Yeni Kustanti dan Reni Pradita et.al., 2017).

Terdapat satu penelitian lain yang hasil nya bertolak belakang dengan hasil peneliti yaitu Kolmodin yang menunjukkan bahwa self-efficacy responden pada penelitian cenderung tinggi, demikian pula perilaku kepatuhan terhadap pengobatan ARV. Hal ini dianggap sejalan oleh Kolmodin dengan hasil analisis bivariat yang menunjukkan ada hubungan antara self-efficacy dengan kepatuhan minum obat antiretroviral (ARV) pada pasien HIV-AIDS. Berdasarkan hasil tersebut dapat dikatakan bahwa peningkatan self-efficacy dapat meningkatkan pula kepatuhan pasien dalam pengobatan (Kolmodin Macdonell, 2016 ; Triani. Dirgantari et al., 2019 ). perbedaan pendapat dan hasil jika di bandingkan dengan hasil peneliti karena pada penelitian tersebut menjelaskan adakah hubungan antara self efficacy dengan kepatuhan pengobatan sedangkan peneliti hanya mengambarkan hasil daripada self efficacy pada ODHA di Provinsi Bengkulu

Dari beberapa pendapat diatas menunjukan bahwa sebagian besar ODHA sudah cukup baik dalam memanajemen perasaan tertekan, memanajemen terapi dan kepatuhan obat, keyakinan dalam mengelola gejala, keyakinan dalam berkomunikasi dengan penyediaan layanan kesehatan terkait masalah kesehatan yang dihadapi, keyakinan untuk mendapatkan dukungan dari orang lain serta keyakinan mengelola kelelahan yang dialami (Mey et.al., 2017). 
2. Pembahasan Tingkat Spiritual

Berdasarkan hasil tabulasi data didapatkan bahwa sebagian besar ODHA di Provinsi Bengkulu memiliki Tingkat Spiritual yang tinggi dimana keseluruhan responden yang diteliti dapat diketahui 1 orang spiritual nya kurang, 8 orang spiritualnya sedang, dan sisanya 41 orang spiritual tinggi, penelitian ini sejalan dengan penelitian yang dilakukan oleh (Tirtanti Prawita Sari, 2019) dalam penelitiannya yang berjudul "Hubungan Tingkat Spiritualitas Dengan Tingkat Stres Pada Odha Di Poli VCT RSD Balung Jember" bahwa sebagian besar responden memiliki tingkat spiritualitas yang tinggi, dimana didapatkan hasil bahwa 49 orang dari 84 responden masuk kedalam kategori spiritual tinggi dengan persentase $58 \%$. Didalam penelitian yang dilakukan oleh (Lusiana, 2018) juga didapatkan hasil bahwa sebagian besar ODHA itu memiki Spiritual Tinggi pendapat ini terbukti dengan tabulasi pada kategori Spiritual Tinggi didapatkan jumlah subjek 10 orang dan presentase $25 \%$, kategori sedang 8 orang dan persentase $20 \%$, dan kategori rendah 8 orang dan persentase $20 \%$ namun, karena pada penelitian ini mencangkup hubungan spiritual dengan variabel kualitas hidup maka pada kesimpulan mengatakan bahwa ada hubungan positif antara spiritualitas dan kualitas hidup pada orang dengan HIV/AIDS.

Tingkat spiritualnya tinggi dan menjadikan quality of life mereka jadi lebih baik. Sementara 3 orang mengatakan tingkat spiritualnya cukup menjadikan quality of life mereka sementara baik. Selain itu 2 orang mengatakan tingkat spiritualnya rendah menjadikan quality of life kurang. Hasil ini sejalan dangan penelitian yang dilakukan oleh I Gede dengan judul "Hubungan Tingkat Spiritualitas antara Quality of Life pada Orang dengan HIV/AIDS Di KDS Kosala Bali” dan didapatkan hasil bahwa hubungan kedua variabel tersebut memiliki arah positif artinya semakin baik tingkat spiritualitas dari ODHA itu sendiri, maka semakin tinggi quality of life nya. 


\section{SIMPULAN DAN SARAN}

\section{SIMPULAN}

1. Sebagian besar ODHA di Provinsi Bengkulu dalam penelitian ini memiliki self efficacy yang cukup dalam mengelola perasaan tertekan,mengelola terapi dan kepatuhan obat, mengelola gejala penyakit yang timbul, berkomunikasi dengan penyedia layanan kesehatan, memperoleh dukungan dari orang lain, serta mengelola kelelahan akibat penyakit hal ini terbukti dalam hasil penelitian bahwa sekitar 24 Orang dari 50 responden masuk kedalam kategori ODHA dengan Self Efficacy yang cukup.

2. Sebagian responden ODHA di Provinsi Bengkulu memiliki Tingkat Spiritual Tinggi dimana hal ini didukung dengan hasil penelitian bahwa dari 50 responden 41 orang masuk dalam kategori memiliki tingkat spiritual tinggi, 8 orang diantaranya masuk kedalam kategori sedang, dan 1 orang sisanya masuk sebagai tingkat spiritual rendah.

\section{SARAN}

1. Bagi Lembaga Swadaya Masyarakat/LSM

Sangat baik lagi bila melakukan konsultasi yang terjadwal kepada setiap ODHA yang terdaftar di LSM tersebut agar bisa menjalin hubungan yang baik sekaligus menambah motivasi bagi ODHA untuk terus meningkatkan kemampuan dirinya dan juga meningkatkan kesejahteraan spiritual dalam dirimya.

2. Bagi UPTD Puskesmas

Sebaiknya juga meningkatkan konsultasi dan bimbingan mengenai kesehatan ODHA tidak hanya berfokus kepada jadwal ARV agar bisa ODHA lebih terbuka tentang kesulitan - kesulitan yang dia hadapi ketika dalam masa pengobatan.

3. Bagi Pendidikan Keperawatan

Penelitian ini dapat menjadi tambahan literature bagi institusi keperawatan mengenai aspek self efficacy dan spiritual guna menciptakan perawat yang berkarakteristik terhadap manajemen diri dan spiritual yang baik untuk pasien dengan HIV/AIDS. 
4. Bagi Orang dengan HIV/AIDS (ODHA)

ODHA diharapkan dapat menambah pengetahuan tentang Self Efficacy dan tingkat Spiritual agar bisa mengoptimalkan sumber dukungan dan bimbingan yang ada dan terdekat, ODHA disarankan lebih sering berkomunikasi dengan penyedia layanan kesehatan. ODHA disarankan bisa ikut serta dalam kelompok dukungan sebaya agar memperoleh dukungan masukan rekan sesama penderita sehingga dapat lebih mengatasi persoalan terkait penyakit HIV tersebut.

5. Bagi Peneliti lain

Hasil penelitian merupakan data dasar untuk penelitian selanjutnya. Peneliti berharap adanya penelitian lanjut terkait faktor - faktor lain yang mempengaruhi tingkat kecemasan pada pasien ODHA khususnya Di Provinsi Bengkulu.

\section{DAFTAR RUJUKAN}

Bahar, R. N. A. (2016). Peran spiritualitas dan kepuasan hidup terhadap kualitas hidup pada wirausahawan muda. Humanitas: Jurnal Psikologi Indonesia, 13(2), 122134.

Wilandika, A. (2018). Religiosity and Self-Efficacy in the Prevention of HIV-Risk Behaviours among Muslim University Students. Jurnal Ners, 13(2), 138-143.

Banna, T., \& Pademme, D. (2019). HUBUNGAN SELF-EFFICACY DENGAN KEPATUHAN MINUM OBAT ANTIRETROVIRAL (ARV) PADA PASIEN HIV-AIDS DI PUSKESMAS KOTA SORONG. Jurnal Keperawatan, 8(2), 21-25.

Collein, I. (2010). Makna spiritualitas pada pasien HIV/AIDS dalam konteks asuhan keperawatan (Doctoral dissertation, Tesis (tidak Dipublikasi). Jakarta: Fakultas Ilmu Keperawatan Universitas Indonesia).

Kustanti, C. Y., \& Pradita, R. (2018). Self Efficacy Penderita Hiv/Aids Dalam Mengkonsumsi Antiretroviral Di Lembaga Swadaya Masyarakat Kebaya Yogyakarta. 
Putra, I. (2020). HUBUNGAN TINGKAT SPIRITUALITAS ANTARA QUALITY OF LIFE PADA ORANG DENGAN HIV/AIDS DI KDS KOSALA BALI (Doctoral dissertation, Sekolah Tinggi Ilmu Kesehatan Buleleng).

Sari, T. P. Hubungan Tingkat Spiritualitas dengan Tingkat Stres pada ODHA di Poli VCT RSD Balung Jember (Doctoral dissertation, Program Studi Ilmu Keperawatan Fakultas Keperawatan Universitas Jember).

Superkertia, I. G. M. E., Astuti, I. W., \& Lestari, M. P. L. (2016). Hubungan antara tingkat spiritualitas dengan tingkat kualitas hidup pada pasien HIV/AIDS di Yayasan Spirit Paramacitta Denpasar. Jurnal Keperawatan Coping Ners, 4(1), 49-53.

YANTI, M. S. (2018). HUBUNGAN TINGKAT SELF EFFICACY DAN DUKUNGAN SOSIAL TEMAN SEBAYA DENGAN PENERIMAAN DIRI KLIEN HIV POSITIF DI PUSKESMAS DUPAK SURABAYA (Doctoral dissertation, Universitas Airlangga). 